\title{
Factors Affecting the Provision of Quality Service in Real Estate Agency in Lagos Metropolis, Nigeria
}

\author{
Funmilayo Moyinola Araloyin (Corresponding author) \\ Department of Estate Management, Obafemi Awolowo University \\ Ile-Ife, Osun State, Nigeria \\ Tel: +23-480-3817-0428_E-mail: funmiolasanmi@yahoo.com \\ OJO Olatoye \\ Department of Estate Managemen, Obafemi Awolowo University \\ Ile-Ife, Osun State, Nigeria
}

Received: January 12, $2011 \quad$ Accepted: February 5, $2011 \quad$ doi:10.5430/ijba.v2n1p71

\begin{abstract}
Real estate firms attempting to increase and retain their customers need to know the factors contributing to customers' satisfaction and retention. This study investigate into real estate agency market with the purposes of identifying factors that affect quality in service provision and possible factors contributing to customers' satisfaction and retention in real estate agency. This study uses survey questionnaires to obtain information from real estate consumers. This sample size consisted of two hundred and three (203) real estate consumers in Lagos metropolis. A survey of 203 real estate consumers revealed the important items that affect quality in service delivery in real estate agency in the study area. The study found that the most important thing affecting quality in real estate agent is the agent's reputation. The study concluded that a reputable real estate agent will have more satisfied clients and attract repeat businesses.
\end{abstract}

Keywords: Real estate consumers, Real estate agents, Consumers' satisfaction, Consumers' perception, Service quality, Lagos Metropolis

\section{Introduction}

Real estate agency is a process that helps to build the bridge that exists between estate owners and buyers. Real estate agents are key players in the agency market. They help to market a property to the public as well as other real estate agents, as a result reducing buyers' search costs and increasing sellers' expectation. They provide services which are met to be solution to their clients' problems. Johnson, et al (1988) categorized real estate agency as a service sector industry which is characterized as being prescriptively customized. That is, there is a high degree of consumer customization because the buyer is continuously involved in the production process. One study by McDaniel and Louargand (1994) suggested that all service businesses must respond to consumer expectations. However, little concern has been shown for customer satisfaction and retention issues in real estate agency.

The perceptions and expectations of customers and the actual performance of the real estate agents are often at variance. According to Sridhar (2001), quality in service means meeting customers' expectations. Customers judge quality by comparing their expectations with their perceptions of what they receive. The author noted that quality in service is a customer-oriented phenomenon, that is, it is ultimately defined by customer irrespective of organizations internal quality specifications. Therefore there is need to investigate into factors that affect quality in service in order to satisfy customers and hence retain them. It was reasoned that if real estate agents know these factors and they work towards providing them, complaints against real estate agents will be greatly reduced.

It is therefore the aim of this paper to examine the factors which contribute to customer's satisfaction and retention in real estate agency practice in Lagos Metropolis. This is achieved by investigating into the views of real estate agency consumers and bringing out the importance of the factors identified. In the process, the study attempt to discover if the factors affecting service quality from real estate agency customers' perspective are congruous with the factors noted in real estate literature. This study will be of interest to real estate firms who provide agency services as it will highlight to them the needs and expectations of their customers in Lagos Metropolis. This study will also add to the body of knowledge in real estate agency by providing factors that will contribute to customers' satisfaction and retention 


\section{Review of Literature}

From the review of literature, certain factors appear to affect quality in goods production or service provision. Kimmons (2008) identified the size of a firm as an important consideration in the choice of the firm to work with. According to the author, larger firms will pull more businesses compared to smaller ones. In the words of Uusitalo (2001), consumers use firm size to guide their perception and evaluation of a particular firm. Due to the importance of firm size in consumers' perception, Abu (2004) in his thesis used firm size as a basis of categorization for consumers' evaluation of a firm's service quality. According to Odekerken-Schroder et al. (2001), larger firm sizes are seen as giving more anonymous and standard self-service. Size of a physical environment has seen by Forgas (1979), is a factor influencing the extent of social interaction between and among customers and employees.

Daharwal (2006) noted that advertisement is an important feature used to promote the sale of a product. Advertising is an art used to familiarize public with the product by informing of its description uses, its superiority over other brands, sources of its availability and price etc. It can also be defined as the dissemination of information concerning an idea, services or products to compel action in accordance with the interest of advertisers. It involves mass media communication directed towards influencing the end consumer. It helps in product promotion and enables a firm to face the competition in the market for its survival.

Advertising is a powerful tool which individuals, business and non- business organizations use for informing persuading and reminding their target audiences. According to Mathews (2006), the average consumer would not be able to know what to buy without advertisement. Daharwal (2006) and Nowak (2008) noted some advantages of advertising which include: helps in the introduction of new products in the market; promotes the sales of goods and services by persuading the people to buy them; helps in creating a demand and hence a regular production; enables a firm to face competition in the market for its survival; enables a firm to improve its reputation by highlighting its achievements to the public; and helps in maintaining uniformity and stability of prices.

Another factor that affects quality as identified from literature is location. Location is defined as the position or point in physical space that something occupies on earths' surface. Longenecker et al (2005) wrote that the choice of a good location is much more vital to some business than to others. For example, the site chosen for an estate firm can make or break the business because it must be convenient for customers. In contrast, the physical location of the office of a painting contractor is of less importance, since customers do not need frequent access to the facility. A lot of businesses suffer if their site is poorly chosen. According to Buckert (2006), location rules in real estate. One way a company can beat another company in getting sales is by having a superior business location. Good location is very important because more customers can be targeted as they often go to the most convenient place. This in turn can make the business successful, maximize the firm's profit and increase its earnings (Kurtus, 2007).

Segal-Horn (1998) identified the attractiveness of firm as an important consideration in firm's growth. According to the author, a firm's ability to earn a rate of profit in excess of its cost of capital depends upon the attractiveness of the firm and its establishment of competitive advantage over rivals. Industrial organization economics emphasizes firm's attractiveness as the primary basis for superior profitability, the implication being that strategic management is concerned primarily with seeking favourable firm environments, locating attractive segments and strategic groups within firms. According to Buckert (2006), old houses need a little makeover if it hopes to attract a qualified buyer. Most of the work may be cosmetic and relatively inexpensive; for example, a new coat of paint, a few attractive window boxes, a thorough cleaning of floors and carpets. Paint, according to the author is probably a seller's best friend because it makes houses smell fresh and look nice.

Price is another important factor affecting quality. Anderson et al (1997) stated that "the law of demand, namely that the higher the price of a good, the less consumers will purchase, has been termed the most famous law in economics, and the one that economists are most sure of." According to Ellis-Christensen (2003), price elasticity refers to the amount of money each individual consumer is willing to pay for something. People with lower incomes tend to have lower price elasticity, because they have less money to spend. A person with a higher income is thought to have higher price elasticity, since he can afford to spend more. Generally, goods or services offered at a lower price lead to a demand for greater quantity.

Communication according to Narayanan et al (2003) plays a major role in influencing consumer purchases in new product or services. It plays both informative and a persuasive role over the life cycle of goods and services. It is also a strategic part of the marketing process; the message that is relayed to the customer. Frequent communicating with customers enables one to deliver message to them so that they will react to it. Consumers are affected by the communication a firm has with them. This communication adds to the firm's value in the mind of the consumer and builds on their cognitive and emotional ties to the firm. The authors advised that frequent communication should be integrated into customer service process. 
Hemuka (1999) recommended Continuing Professional Development Programmes (CPD) as a vehicle for the advancement of professional and academic knowledge among real estate practitioners. He stressed the need for real estate practitioners to equip themselves with the knowledge they need to meet future challenges. He advised that every state branch of the Nigeria Institution of Estate Surveyors and Valuers should organize at least one Continuing Professional Development Programme each year. He also recommended advanced refresher courses at the national level for fellows, senior associates and the older generation whose ideas and academic knowledge need fine-tuning. He continued by saying that old age comes with diminishing returns, so one need to charge his/her mental batteries.

Anderson et al (1998) wrote that the reputation of a firm could help its selling power, which would increase its efficiency. Older firms may be able to obtain more listings and/or make more sales than their new firm counterparts because of reputation and accumulated brand name capital effects. He noted however that it is possible for older, more established firms to attempt to "ride" on their established reputation and not utilize the resources they have available. Johnson and Loucks (1986) in their study focused on the effect of state licensing regulations on the industry. They found that licensing regulations improve industry's performance.

Webb (2000) in his inquiry into the professional self image of real estate agents discovered that the single most important thing that could be done to enhance the professional image of real estate agents was the "requirement of more education before licensing". He observed that the second most important thing from the perspective of his respondents was "greater emphasis on morals and ethics", followed closely by "stricter enforcement of regulations governing the behavior of real estate agents"

In a study by Guntermann and Smith (1988), the authors relate complaints against real estate licensees to compliance and enforcement efforts by regulators and pre-licensing education requirements. Emphasis was based on the presumption that if licensees know what to do, then service quality will be improved. However, a recent analysis of complaint data based on practitioner surveys suggests that licensees often know what is correct in a given situation but may not do it since doing so is not always in the agent's self-interest. The results therefore suggested that the most effective way to reduce complaints is through vigorous efforts at compliance and enforcement with licensing and education requirements.

Miner (1998) also suggested that there are some tangible items that can affect the quality of a service; the physical service environment, the appearance of the service provider and the pricing of the service. Canziani (1996) suggested that the main elements to consider in achieving a quality service include: collection and measurement of customer data; benchmarked standards for work processes and outputs; goals and action plans specifying quality outputs; personnel trained in the use of tools and teams and a culture that empowers and rewards service employees.

From the review of literature, it was revealed that the following factors could affect the production/provision of goods/services. These factors include; size of firm, advertisement, location, attractiveness of office, prices, communication, professional development programmes, reputation of firm, education, moral and ethics, the physical service environment, the appearance of the service provider, the pricing of the service and vigorous efforts at compliance and enforcement with licensing and education requirements. In this study, some of the factors identified were put to test in order to ascertain if these factors could affect quality in real estate agency service delivery.

\section{The Study Area}

The study area for this research work is Lagos Metropolis. Ideally, the study should consider the whole country but for manageability and thorough analysis, to was restricted to this area. The restriction to Lagos metropolis was informed by the fact that the metropolis is one of the most important commercial cities as the volume of economic activity in metropolitan Lagos exceeds that of all capitals or towns in the country. Also the vast majority of firms of estate surveyors and valuers who are involved in real estate practice have their head offices or branch offices located in the metropolis. The membership directory of the Nigerian Institution of Estate Surveyors and Valuers (2002 edition) showed that approximately $54 \%$ of estate surveying firms in Nigeria are based in Lagos metropolis.

\section{Methodology}

The study was conducted in Lagos metropolis in February 2009. The focus group for this research work was mainly real estate service consumers. This comprises home owners, home buyers and tenants who employ the services of estate agents whether in search of a prospective tenant or a property. 118 estate surveying firms were randomly selected representing $50 \%$ of the total number of estate surveying firms in the study area. This is believed to be a fair representation of the entire population. From each estate surveying firm, two (2) service consumers were purposively selected given rise to a total number of 236 real estate service consumers. The study adopted self-administered questionnaire as its data collection instrument. 
Each consumer was asked to complete a questionnaire. The questions focused on factors influencing the provision of quality service in real estate agency. More specifically, consumers were asked to rate the factors in their order of importance. The factors that were tested were derived from literature related to real estate agency and service quality in general.

\subsection{Data Collection}

A total number of 236 questionnaires were administered to real estate agency consumers but 207 questionnaires were retrieved. 4 responses were found unusable. Valid responses totaled 203, an $86 \%$ response rate which is relatively high despite the nature of the sample (people who are busy, non-homogenous and not predisposed to complete a questionnaire). The authors believed that the sample fairly represents the population surveyed.

\section{Results and Discussion}

The consumers were asked to complete a questionnaire relating to issues that affect quality in real estate agency service delivery. The following are highlighted extracts from the results of the 2009 real estate consumer survey carried out in Lagos metropolis, Nigeria.

\subsection{Sample characteristics of participants}

The sample characteristics for real estate consumers that participated in the study are shown in Table 1 . The consumers consist of $77.3 \%$ male and $22.7 \%$ female. The relatively large number of male agents is not unexpected considering the strenuous nature of the agency business. The average consumer was between the ages of $36-50$ years old and had an average annual income of over N400, $000.56 .3 \%$ of real estate consumers were married, $38.8 \%$ single and the remaining $4.9 \%$ divorced.

$<$ Table 1 about here $>$

The 203 consumers that were surveyed had an average length of 10 years experience in real estate related businesses. Majority of the consumers were civil servant and have a graduate degree as the highest level of education attained. From this outcome, it may be deduced that most of the consumers are qualified to know the importance of research and can be relied on to give reliable information. Therefore the credibility of the data is sustained and the information obtained actually reflects the view of real estate service consumers in the subject under study.

\subsection{Real Estate Agents' Performance}

The real estate service consumers were asked to assess the performance of their agents. They were to pick an option ranging from incompetent to excellent. Table 2 documents how the consumers regard their real estate agent.

The results as documented in Table 2 showed respondents' perception to how real estate consumers view real estate agents. The middle response (average) had the highest frequency - ninety-seven responses representing $47.8 \%$ of the total. This implies that real estate consumers regard the average real estate agent as a person who understands what he/she is doing and know how to meet the needs of his/her client. However, none of the real estate consumers rated their agent as excellent. This means there is need for improvement in their mode of service delivery.

$<$ Table 2 about here $>$

\subsection{Service Delivery}

Another question was asked pertaining to real estate agents' service delivery. Figure 1 showed the details of the responses. The consumers were expected to rank the overall quality of services provided by estate agents. The answer to the question ranking the overall quality of services provided by estate agents supports the above findings. The responses showed that $2.2 \%$ found the quality of services to be very poor, $7.9 \%$ agreed that the services are poor, $33 \%(67)$ believed that their services need improvement, $16.4 \%$ rated the services as average, $26 \%$ good, $9.6 \%$ very good and $4.9 \%$ as excellent.

$<$ Figure 1 about here $>$

Majority of the consumers reported that the quality of services provided by the estate agents needs improvement. The result indicates that the mode of service delivery in real estate agency I Lagos metropolis needs improvement and special attention needs to be drawn to this fact.

\subsection{Factors Affecting the Provision of Service Quality}

The following factors were put to test and the respondents were expected to strongly disagree or strongly agree if those factors could improve the quality of services rendered by real estate agents. There were twelve (12) factors in the list generated from literature. The findings are as provided in Table 3. 
$<$ Table 3 about here $>$

The results were ranked in order of importance. Table 4 presented the details of the findings.

$<$ Table 4 about here $>$

The result of analysis as presented in Table 4 revealed that the most important factor that affects quality in real estate agency from consumers' perspective was the real estate agent's reputation. This factor has the highest mean score of 63.6 and therefore was rated as the most important factor. Real estate agent's reputation has to do with the opinion that people have about the agent based on what has happened in the past. The researcher realized that there are some real estate agents in this country that have made good names for themselves because they have performed well in the past and their customers were always proud to be associated with them. It therefore implies that agents need to create a good first impression as this will form the basis for assessing their reputation.

The second most important thing that the respondents felt could affect the quality of service delivery in real estate agency is the size of real estate firm with a mean score of 61.6. The size of a firm refers to the volume of the workforce and also the extent or space the firm occupies. The study observed that in large estate firms, there are various departments (e.g. agency, valuation, management etc.) and this gives room for specialization. The reverse is the case in small firms. All the workers are involved in the various aspects the profession.

The study revealed that the third most important thing that could be affect quality in real estate agency was to have more regulations to govern the behaviour of real estate agents. This factor had a mean score of 59.1 and was rated third in the order of importance. In a study by Guntermann and Smith (1988), emphasis was based on the presumption that if real estate agents know what to do, then service quality will be improved. The authors also suggested that regulations should be supported by vigorous effort at compliance and enforcement.

The fourth most important factor was the amount of advertising provided by the real estate firm. Advertising as defined in literature is the art of familiarizing the public with a product (property) by informing of its description uses, location, number of rooms, construction details, asking price or rent etc. This result shows that advertising play an important role in persuading a prospective buyer or tenant and reminding them of available services. This component was closely followed by stricter enforcement of regulations governing the behaviour of estate agent. This has to do with limiting the freedom of estate agents in such a way that they conform to the regulations of the governing council and that they should be severely punished if they disobey.

Frequent communication with the estate agent during the transaction period received the sixth position with a mean score of 57.1. This means exchanging of information as many times as possible estate agents and their clients. This could be done either through telephone calls, text messages, face to face conversation, announcements, publications in property bulletins etc. The next in the order of importance is the location of the estate firm. According to Buckert (2006), location rules in real estate. The location is the position of a place and needed to be accessible, that is easy to reach, enter, and be seen. There may also be need for sign post to direct customers aright.

The next in order of importance was price range of property offered. It was observed that majority of the consumers are price-conscious, that is they avoid buying expensive things. They want high property value at lowest possible cost. However, this was followed at an insignificantly small distance by more continuing education programmes. This could best be organized at state or national levels by the Nigeria Institution of Estate Surveyors and Valuers (NIEVS). This according to the respondents is the ninth most important thing that could affect quality in real estate agency service delivery.

Other factors affecting quality in real estate agency service delivery were; the attractiveness of the real estate office, emphasis on morals and ethics, and the real estate agent's effort to make the closing go smoothly. The study however observed that all these factors play significant role in ensuring good service delivery in real estate agency as they all received a mean score greater than 50 . The study therefore advice that real estate agents should pay close attention to these factors as they are important in ensuring good service delivery.

\section{Conclusion}

The paper focused on the factors that real estate consumers consider relevant in real estate agency service delivery. The results of this paper provide strong evidence that real estate agent's reputation is the most important thing that affects quality in real estate agency in Lagos metropolis. This implies that real estate agency consumer's judge their agents based on public opinion and what they have done in the past. The results of this study suggest that despite real estate agent's attempt to improve their service delivery or please their consumers, their conduct in their first contact with consumers has a lot to done with agent's reputation. Other factors relevant to quality in real estate agency include; size 
of the real estate firm, regulations to govern the behaviour of real estate agent, amount of advertising provided by the real estate firm, enforcement of regulations governing the behaviour of estate agent, frequent communication etc. The study recommended that real estate agent to should try and create a first good impression as this has a long way to go in affecting consumers opinion about them.

\section{References}

Abu, N.K. (2004). Service Quality Dimensions: A Study on Various Sizes of Grocery Retailers, A conceptual Paper, Faculty of Business Administration, Universiti Tun Abdul Razak, Kelana Jaya, Selangor, Malaysia.

Anderson, P.L., McLellan, R.D., Overton, J.P., \& Wolfram, G.L. (1997). Price Elasticity of Demand, Mackinac Centre for Public Policy, from http://www.mackinac.org/article.aspx

Anderson, R.I, Fok, R., Zumpano, L.V \& Elder, H.W. (1998). Measuring the Efficiency of Residential Real Estate Brokerage Firms, Journal of Real Estate Research, Vol. 16 No. 2, pp. 139-152.

Buckert Realty Group (2004). 3901 N. Main Victoria, Texas 77901 361-572-8200.

Canziani, B. (1996). 'Integrating Quality Management and Customer Service: The Service Diagnostics Training Scheme"' in Service Quality in Hospitality Organization, Editors: Olsen, D., Teare, R., Gummesson, E., Cassell, New York pp. $140-163$.

Daharwal, S.J. (2006). Internet Marketing Newsletter; from www.internetmarketingnewsletter.com

Ellis-Christensen, T. (2003). What is Price Elasticity of Demand?, wiseGEEK features, from http://www.wisegeek.com.

Forgas, J. P. (1979). Social Episodes, London, Academic Press, Inc., in Bitner, M.J. (1992). Servicescapes: The Impact of Physical Surroundings on Customers and Employees, Journal of Marketing, 56 (April), 57-71.

Guntermann, K.L. \& Smith, R.L. (1988). Licensing Requirements, Enforcement Effort and Complaints against Real Estate Agents, Journal of Real Estate Research, Vol. 3 No. 2, pp. 11-20

Johnson, J.M., Nourse, H.O., \& Day, E. (1988). Factors Related to the Selection of a Real Estate Agency or Agent, Journal of Real Estate Research, Vol. 3 No. 2, pp. 109-118.

Johnson, L.L., Dotson, M.J., \& Dunlap, B.J. (1988). Service Quality Determinants and Effectiveness in the Real Estate Brokerage Industry, Journal of Real Estate Research, Vol. 3; No. 2, pp. 21-36.

Johnson, L.L., \& Loucks, C. (1986). The Effect of State Licensing Regulations on the Real Estate Brokerage Industry, Journal of the American Real Estate and Urban Economics Association, 14:4, 567-82. doi:10.1111/1540-6229.00404, http://dx.doi.org/10.1111/1540-6229.00404

Kimmons, J. (2008). Choosing A Commercial Real Estate Firm, Looking at Brokerage Size, Small or Large - Which is Right for You?

Kurtus, R. (2007). Using Location for a Competitive Advantage in Business, from http://www.school-for-champions.com/

Longenecker, J.G., Moore, C.W., Palich, L.E., \& Petty, J.W. (2005). Small Business Management: An Entrepreneurial Emphasis, Published by Cengage Learning.

Mathews, M. (2006). Advertising's Role in Business, Society, from http://www.associatedcontent.com

McDaniel, J.R. \& Louargand M.A. (1994). Real Estate Brokerage Service Quality: An Examination, Journal of Real Estate Research, Vol. 9 No. 3, pp. 339-351.

Miner, P.L. (1998). Meeting the Customer's Expectations - Quality Considerations for the Service Components of Outbound Inclusive Tour Operating, Master of Business Administration Dissertation, Henley Management College.

Narayanan, S., Manchanda, P., \& Chintagunta, P.M. (2003). The Informative Versus Persuasive Role of Marketing Communication in New Product Categories: An Application to the Prescription Antihistamines Market, Stanford Graduate School of Business, 518 memorial Way, Stanford, CA 94305-5015, United States.

Nowak, A. (2008). The Role of Words in Advertising, Free Online Articles Directory, from www.articlebase.com

Odekerken-Schroder, G., De Wulf, K., Kasper, H., Kleijnen, M., Hoekstra, J. \& Commandeur, H. (2001). The Impact of Quality on Store Loyalty: A Contingency Approach, Total Quality Management, 12 (3), 307-322. doi:10.1080/09544120120034474, http://dx.doi.org/10.1080/09544120120034474 
Segal-Horn, S. (1998). The Strategy Reader, Published by Wiley-Blackwell, ISBN 0631209018, 9780631209010.

Sridhar, M.S. (2001). Service Quality and Customer Satisfaction, Being a Lecture delivered in UGC Refresher Course on "Library and Information Science" at Academic Staff College of Bangalor University.

Webb, J.R. (2000). An Inquiry into the Professional Self Image of Real Estate Agents, Journal of Real Estate Research, Vol. 20, No. 1/2, pp. 153-177.

Table 1. Sample Characteristics of Participants

\begin{tabular}{|c|c|c|}
\hline \multirow{2}{*}{ Real Estate Service Consumers (203) } \\
\hline \multirow{4}{*}{ Age } & $<35$ & $59.1 \%$ \\
\cline { 2 - 3 } & $36-50$ & $34.0 \%$ \\
\cline { 2 - 3 } Education & $>50$ & $6.9 \%$ \\
\cline { 2 - 3 } & Graduate Degree & $46.8 \%$ \\
\cline { 2 - 3 } & Masters Degree & $37.9 \%$ \\
\hline \multirow{4}{*}{ Sex } & Others & $14.8 \%$ \\
\hline Year of Experience & Male & $77.3 \%$ \\
\hline Marital Status & Female & $22.7 \%$ \\
\cline { 2 - 3 } & Mean & $10 y e a r s$ \\
\cline { 2 - 3 } & Single & $56.3 \%$ \\
\hline Occupation & Divorced & $38.8 \%$ \\
\cline { 2 - 3 } & Civil Servant & $4.9 \%$ \\
\cline { 2 - 3 } & Self Employed & $36.2 \%$ \\
\hline Annual Income & Others & $94.5 \%$ \\
\cline { 2 - 3 } & N100,000-N400,000 & $22.7 \%$ \\
\cline { 2 - 3 } & $>$ N400, 000 & $51.7 \%$ \\
\hline
\end{tabular}

Source: Authors' Field Survey (2009).

Table 2. Real Estate Consumers' Opinion of a Real Estate Agent

\begin{tabular}{|c|c|c|}
\hline Ranking & Consumers & Number \\
\hline Incompetent & 0.0 & 0 \\
\hline Poor & 6.9 & 14 \\
\hline Average & 47.8 & 97 \\
\hline Good & 45.3 & 92 \\
\hline Excellent & 0.0 & 0 \\
\hline Total & 100 & 203 \\
\hline
\end{tabular}

Source: Author's Field Survey (2009) 
Table 3. Items Affecting Quality in Real Estate Agency Service Delivery

\begin{tabular}{|l|c|c|c|}
\hline \multicolumn{1}{|c|}{ Factors } & Disagree & Neutral & Agree \\
\hline The size of the real estate firm & 32.5 & 5.9 & 61.6 \\
\hline The amount of advertising provided by the real estate firm & 28.0 & 22.9 & 59.1 \\
\hline The location of the real estate office & 26.0 & 17.7 & 56.2 \\
\hline The attractiveness of the real estate office & 22.6 & 24.6 & 52.7 \\
\hline The price range of property offered & 34.0 & 12.3 & 53.7 \\
\hline The real estate agent's effort to make the closing go smoothly & 28.1 & 20.2 & 51.7 \\
\hline Frequent communication with the estate agent during the transaction period & 25.1 & 17.7 & 57.1 \\
\hline The real estate firm's reputation & 18.7 & 17.6 & 63.6 \\
\hline Stricter enforcement of regulations governing the behaviour of estate agent & 18.7 & 23.2 & 58.1 \\
\hline More continuing education programmes & 20.6 & 26.1 & 53.2 \\
\hline More regulations to govern the behaviour of real estate agent & 26.6 & 16.3 & 59.1 \\
\hline Emphasis on morals and ethics & 23.2 & 24.1 & 52.7 \\
\hline
\end{tabular}

Source: Author's Field Survey (2009)

Table 4. Importance of the items affecting Quality in Real Estate Agency Service Delivery

\begin{tabular}{|l|c|c|c|}
\hline \multicolumn{1}{|c|}{ Factors } & Rank & Mean Score & Number \\
\hline The real estate agent's reputation & 1 & 63.6 & 129 \\
\hline The size of the real estate firm & 2 & 61.6 & 125 \\
\hline Regulations to govern the behaviour of real estate agent & 3 & 59.1 & 120 \\
\hline The amount of advertising provided by the real estate firm & 4 & 59.1 & 120 \\
\hline Stricter enforcement of regulations governing the behavior of estate agent & 5 & 58.1 & 118 \\
\hline Frequent communication with the estate agent during the transaction period & 6 & 57.1 & 116 \\
\hline The location of the real estate office & 7 & 56.2 & 114 \\
\hline The price range of property offered & 8 & 53.7 & 109 \\
\hline More continuing education programmes & 9 & 53.2 & 108 \\
\hline The attractiveness of the real estate office & 10 & 52.7 & 107 \\
\hline Emphasis on morals and ethics & 11 & 52.7 & 107 \\
\hline The real estate agent's effort to make the closing go smoothly & 12 & 51.7 & 105 \\
\hline
\end{tabular}

Source: Author's Field Survey (2009) 


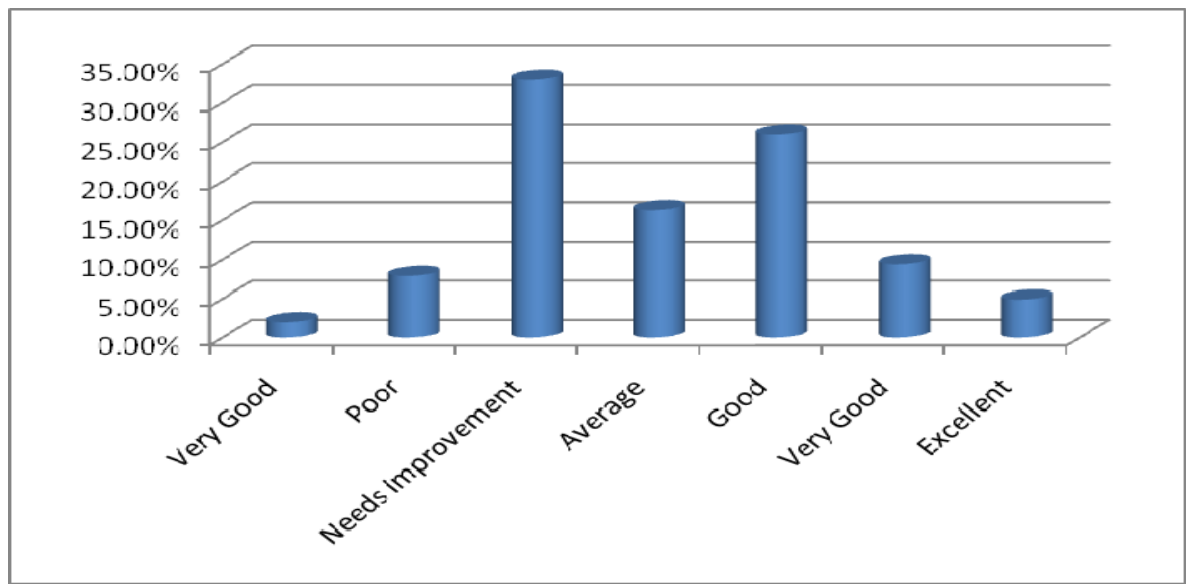

Figure 1. Quality Rating in Real Estate Agency Practice

Source: Author's Field Survey (2009) 